\title{
Effect of phytohormones on shoot apex and leaf explants of Withania somnifera (Ashwagandha)
}

\author{
Archana Rani*, M. Kumar and Sanjeev Kumar ${ }^{1}$ \\ Department of Agricultural Biotechnology and Molecular Biology, (FBS \& H), Rajendra Agricultural University, \\ Pusa-848125 (Bihar), INDIA \\ ${ }^{1}$ Department of Plant Pathology, College of Agriculture, Jawaharlal Nehru Krishi Vishwa Vidayalaya Jabalpur- \\ 482004 (M.P.), INDIA \\ *Corresponding author. E-mail: archanarani22oct@gmail.com
}

Received: July 22,2015; Revised received: December 17, 2015; Accepted: March 14, 2016

\begin{abstract}
An efficient protocol for callus induction of Withania somnifera through in vitro culture of shoot apex and leaf explant was standardized. Of the various combinations of phytohormones evaluated, MS media supplemented with 6-furfuryl aminopurine (KIN) $0.5 \mathrm{mg} / \mathrm{l}+2$,4-dichlorophenoxy acetic acid (2, 4-D) $2.0 \mathrm{mg} / \mathrm{l}$ was found to be best for mean callus induction (86\%) in leaf explants after 6 weeks of culture and in case of shoot apex expant the best response and growth of callusing was observed on MS medium supplemented with 2,4-D 1.0 mg/l + BAP $2.0 \mathrm{mg} / \mathrm{l}$ $(77 \%)$. The response of callus growth increases gradually with the reductions in concentration of KIN in culture medium of both the explants. This protocol might be used in further research for mass propagation of $W$. somnifera via indirect regeneration methods.
\end{abstract}

Keywords: Callus induction, Leaf and shoot apex explants, Withania somnifera explant

\section{INTRODUCTION}

Withania somnifera Dunal, a member of Solanaceae is commonly known as 'Ashwagandha' $(2 \mathrm{n}=48)$ or 'Indian ginseng'. It is a much-valued medicinal plant with immense therapeutic applications including anti-stress, anti-depressant, adaptogenic, rejuvenative, aphrodisiac, anticancerous immunomodulatory, haematopoietic properties and antioxidant body building herb with great promises (Vadawale et al., 2004; Shanmugaratnam et al., 2013). It is an abortifacient, amoebicide, anodyne, bactericide, contraceptive, diuretic, emmenagogue, fungicide, narcotic, pediculicide, sedative, spasmolitic, adaptogenic and tonic. Leaves are used for curing fever, lesions, swelling, sore eyes and syphilitic sores. Green berries are used for treating ringworm infection, animal sores and horse's girth galls (Rajeswara Rao et al., 2012). Ashwagandha has high demand (500 tonnes, during 1999) in pharmaceutical industries, $50 \%$ of which is met through harvesting of wild population (NRIF, 2004). Extensive cultivation of this species is being done in many tropical regions of India. Ashwagandha has been falling down from its natural habitat and is now included in the record of endangered species (Rani et al., 2015 a Patel and Krishnamurthy, 2013) by the International Union for Conservation of Nature and Natural Resources (Kavidra et al., 2000; Supe et al., 2006). Conventional propagation is achieved through seeds but the seed viability is limited to one year (Waman et al., 2011; Rout et al., 2011.) and success rate of vegetative propagation in $W$. somnifera is very low (Kulkarni et al., 2000; Vadawale et al., 2004). There are variation in the concentration and quantities of secondary metabolites in field grown plants as biosynthesis of secondary metabolites, although controlled genetically, is affected strongly by environmental influence.

The use of plant cell and tissue cultures has overcome several inconveniences for the production of the secondary metabolites, which is an alternative approach to traditional agriculture in the industrial production of these bimolecules. Schielder (1985) reported that plant cell and tissue culture, as well as genetic engineering may be an alternative to the conventional method for the improvement of medicinal plants. The root, stem and leaves of regenerated plants or the induced callus may be used fresh or dried, as raw drugs or different secondary metabolite are extracted from them. Callus culture consists of an undifferentiated, proliferating mass of cells generally originating on wounds of differentiated tissues and cells. Normally juvenile and therefore physiologically the most active tissues provide better callus formation. The exogenous phytohormone is essential for callus formation (Pierik, 1987; Adhikari et al., 2013). Callus induction is highly influenced by the growth/nutrient medium supplemented with different concentrations 
and combinations of phyto hormones (Gibson et al., 1995; Adhikari et al., 2013). There are several reports on in vitro callus induction and production of secondary metabolites in medicinal plants (Hina et al., 2012; Rani et al., 2015 b). However there are very few reports are available on callus induction using different explants of $W$. somnifera (Rani and Grover, 1999; Rani et al., 2003; Rani et al., 2014). Therefore, the present study was aimed to show the procedure for the callus induction and culture of $W$. somnifera following standard plant tissue culture protocol using different active plant parts, growth regulators and studying their effect on callus induction.

\section{MATERIALS AND METHODS}

The shoots and leaves of about $1.5-2 \mathrm{~cm}$ long were collected from apex of 2 years old plant of $W$. somnifera for standardization of regeneration protocol in Department of Agricultural Biotechnology and Molecular Biology at Rajendra Agricultural University Pusa, Bihar. Collected explants were first washed with running tap water (15 minutes) and then surface sterilized with Tween-20 ( 2 drop/100ml), 70\% ethanol for 1-1 minutes and were rinsed in distilled water thrice. Then, they were taken to the laminar air flow chamber where treated with $0.1 \% \mathrm{HgCl} 2$ for 2 minutes and washed with sterile distilled water. It was then inoculated in the appropriate MS medium, which contained sucrose (3\%), and $\mathrm{pH}$ (5.8). Cutting edge of the explants should make a direct contact with medium. The cultures were incubated at $24 \pm 2^{\circ} \mathrm{C}$ under 2000 lux light intensity provided by white fluorescent lamp for 16 hours photoperiod. The basal MS medium was used with derived supplementation of phytoregulators for callusing. The MS basal media were supplemented with different auxins: D 2,4dichlorophenoxy acetic acid (2,4-D) $0.2-2 \mathrm{mg} / \mathrm{l}$ and cytokinin: Benzyl Amino Purine (BAP) 0.2-1 mg/l and 6-furfuryl aminopurine (KIN) 0.1-0.5 mg/l.

\section{RESULTS AND DISCUSSION}

Callus induction and proliferation from shoot apex and leaves were obtained by inoculating sterile leaves and shoot apex on MS medium supplemented with different concentrations of 2,4-D $(0.2,0.5,1.0,1.5,2 \mathrm{mg} /$ 1), $\operatorname{BAP}(0.2,0.5,1 \mathrm{mg} / \mathrm{l})$ and $\mathrm{KIN}(0.1,0.2,0.4,0.5 \mathrm{mg} / \mathrm{l})$. All the media gave positive response for callus growth. After six weeks of culture, a shinny cream coloured callus were induced on both of the explants. The rate of callus formation was slow in the first two weeks. On the other hand, the callus exhibited good growth and covered the whole explant within 3-4 weeks. To sustain the continuous growth of this callus, again sub cultured on MS medium having the same concentrations of phytohormones. After six weeks of culture, an excellent loose textured friable callus was developed on the pre-existing callus. The major portion of the callus was whitish green/brown, while some portion of the callus showed signs of browning, which may be due to longer culture period. No shoot induction occurred in this combination of the phytohormones used. Out of different combination of phyto hormone tested, KIN $0.5 \mathrm{mg} / 1+2$, 4-D $2.0 \mathrm{mg} / 1$ was found to be best for callus induction percentage and days to callus induction (Plate 1(d)). This combination resulted 86\% of callus induction in leaf in 25 days(Table 2). The average response of callus induction was observed better in MS medium combinations of phyto hormone 2,4-D with KIN than 2,4-D with BAP in both the explants.

Callus formation on shoot apex: In case of shoot apex explants, the best response and growth of callusing was observed on MS medium supplemented with 2,4-D $1.0 \mathrm{mg} / 1$ + BAP $2.0 \mathrm{mg} / 1(77 \%)$ followed by KIN $0.2 \mathrm{mg} / \mathrm{l}+2,4-\mathrm{D} 2.0 \mathrm{mg} / \mathrm{l}(76 \%)$ after 5-6 weeks of primary culture of $W$. somnifera (Plate 1c). The colour of friable callus was whitish green. The minimum response and growth of callusing was observed on MS
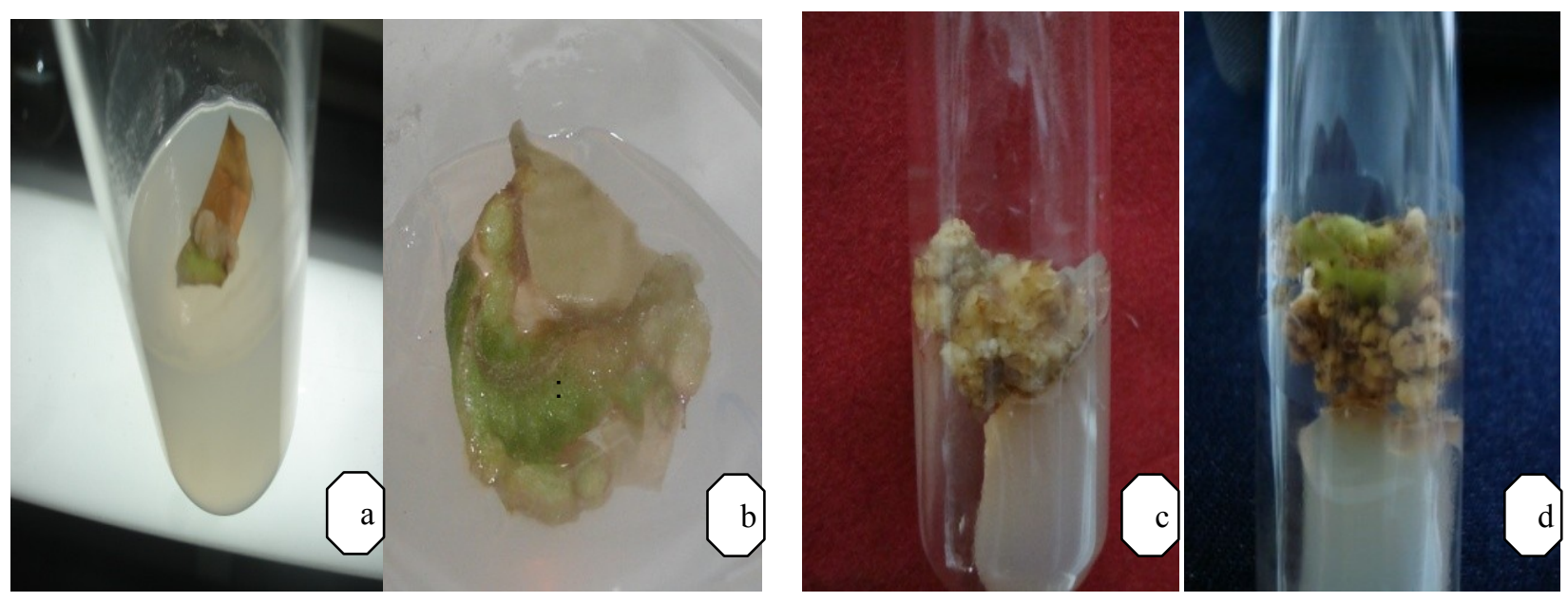

Plate 1. In vitro responses from shoot apex and leaf of W.somnifera (a) Initiation of callus from leaf explant; (b) Proliferation of callus; (c) Callus developed from shoot apex; (d) Callus proliferate from shoot apex. 
Table 1. In vitro response from shoot apex and leaf explants of $W$. somnifera cultured on with different concentrations of 2,4 -D and BAP on MS media.

\begin{tabular}{|c|c|c|c|c|c|}
\hline Explant & $\begin{array}{l}\text { Phytohorm } \\
\text { mg/l 2,4-D }\end{array}$ & $\begin{array}{l}\text { one in } \\
\text { BAP }\end{array}$ & $\begin{array}{l}\text { \% Response of callus } \\
\text { formation }(\mathrm{Mean} \pm \mathrm{SE})\end{array}$ & $\begin{array}{c}\text { Nature and colour } \\
\text { of callus }\end{array}$ & $\begin{array}{l}\text { Growth of } \\
\text { callus* }\end{array}$ \\
\hline \multirow{7}{*}{$\begin{array}{l}\text { Shoot apex } \\
\text { Explant }\end{array}$} & 1.0 & 1.0 & $57.33 \pm 1.45$ & F \& WG & +++ \\
\hline & 1.0 & 0.5 & $77.66 \pm 1.45$ & $\mathrm{~F} \& \mathrm{WG}$ & ++++ \\
\hline & 1.5 & 1.0 & $76.00 \pm 1.73$ & $\mathrm{FC} \& \mathrm{WG}$ & +++ \\
\hline & 0.5 & 1.0 & $39.66 \pm 2.02$ & F \& WG & ++ \\
\hline & 1.0 & 1.0 & $41.66 \pm 2.02$ & F \& WB & + \\
\hline & 2.0 & 0.2 & $62.33 \pm 2.18$ & C \& B & +++ \\
\hline & 0.2 & 0.2 & $36.66 \pm 3.75$ & $\mathrm{FC} \& \mathrm{WG}$ & + \\
\hline \multirow[t]{7}{*}{ Leaf Explant } & 1.0 & 1.0 & $58.66 \pm 1.45$ & F \& W & +++ \\
\hline & 1.0 & 0.5 & $75.00 \pm 1.45$ & $\mathrm{~F} \& \mathrm{WG}$ & ++++ \\
\hline & 1.5 & 1.0 & $65.66 \pm 1.73$ & FC \& W & +++ \\
\hline & 0.5 & 1.0 & $46.00 \pm 2.02$ & $\mathrm{~F} \& \mathrm{~W}$ & ++ \\
\hline & 1.0 & 1.0 & $47.33 \pm 2.02$ & $F \& B$ & ++ \\
\hline & 2.0 & 0.2 & $61.00 \pm 2.18$ & $F \& B$ & +++ \\
\hline & 0.2 & 0.2 & $33.33 \pm 3.75$ & $F \& G W$ & + \\
\hline
\end{tabular}

*Visual observation; number of + sign indicates relative amount of callus; - = no response; $\mathrm{W}=$ white; $\mathrm{B}=$ brown; F=friable; $\mathrm{SF}=$ semifriable

Table 2. In vitro response from different explants of $W$. somnifera cultured on MS media with different concentrations of KIN and 2, 4-D.

\begin{tabular}{|c|c|c|c|c|c|}
\hline \multirow{2}{*}{$\begin{array}{l}\text { Explant } \\
\text { Shoot apex Explant }\end{array}$} & \multicolumn{2}{|c|}{$\begin{array}{l}\text { Phytohormone in } \mathrm{mg} / \mathrm{l} \\
\text { KIN 2,4-D }\end{array}$} & \multirow{2}{*}{$\begin{array}{c}\begin{array}{c}\text { \% Response of } \\
\text { Callus formation } \\
(\text { Mean } \pm \text { SE) }\end{array} \\
64.33 \pm 2.96\end{array}$} & \multirow{2}{*}{$\begin{array}{c}\begin{array}{c}\text { Nature \& colour } \\
\text { of callus }\end{array} \\
\text { F \& WG }\end{array}$} & \multirow{2}{*}{$\begin{array}{c}\begin{array}{c}\text { Growth of } \\
\text { callus* }\end{array} \\
++++\end{array}$} \\
\hline & 0.1 & 2.0 & & & \\
\hline & 0.2 & 2.0 & $76.00 \pm 3.21$ & F \& WG & ++++ \\
\hline & 0.4 & 2.0 & $66.00 \pm 1.52$ & FC \& WG & +++ \\
\hline & 0.5 & 2.0 & $67.33 \pm 1.76$ & F \& WG & ++ \\
\hline \multirow[t]{4}{*}{ Leaf Explant } & 0.1 & 2.0 & $68.33 \pm 2.72$ & $\mathrm{~F} \& \mathrm{~W}$ & ++++ \\
\hline & 0.2 & 2.0 & $85.66 \pm 2.84$ & $\mathrm{~F} \& \mathrm{WG}$ & ++++ \\
\hline & 0.4 & 2.0 & $84.00 \pm 2.02$ & $\mathrm{FC} \& \mathrm{~W}$ & +++ \\
\hline & 0.5 & 2.0 & $86.00 \pm 1.52$ & $\mathrm{~F} \& \mathrm{~W}$ & ++ \\
\hline
\end{tabular}

${ }^{*}$ Visual observation; number of + sign indicates relative amount of callus; - = no response; $\mathrm{W}=$ white; $\mathrm{B}=$ brown; $\mathrm{F}=$ friable; $\mathrm{SF}=$ semifriable

medium supplemented with 2, 4-D $0.2 \mathrm{mg} / 1+$ BAP 0.2 $\mathrm{mg} / \mathrm{l}(36 \%)$ after 5 weeks of primary culture of $W$. somnifera (Table 1). The colour of friable compact callus was whitish green. Udayakumar et al. (2013) reported that the epicotyl explants produced the most calli in MS medium supplemented with $2.0 \mathrm{mg} / \mathrm{L}$ of 2,4-D in combination with $0.6 \mathrm{mg} / \mathrm{L}$ of kinetin in $W$. somnifera .

Callus formation on leaf explants: The best response of callusing $(86 \%)$ was observed in leaf explants on MS medium supplemented with KIN $0.5 \mathrm{mg} / \mathrm{l}+2$, 4-D $2.0 \mathrm{mg} / \mathrm{l}$ in which callus was obtained in at 6 weeks of culture of $W$. somnifera. Similarly MS media supplemented different with concentrations of KIN 0.4, 0.2, $0.1 \mathrm{mg} / 1$ combined with the same concentration i.e., $2 \mathrm{mg} / \mathrm{l}$ of $2,4-\mathrm{D}$ were also found to be good condition for callus induction on the same explants (Plate 1a,b). The percentage response of callus formation per leaf explants gradually increased with the increasing concentrations of KIN but decrease in growth of callus. Callus induction of $W$. somnifera was observed from hypocotyl, root, and cotyledonary leaf segments on MS medium supplemented with various concentrations and combinations of 2,4-D and KIN (Rani et al., 2003). The minimum response and growth of callusing was observed on MS medium supplemented with 2, 4-D $0.2 \mathrm{mg} / 1+$ BAP $0.2 \mathrm{mg} / 1$ (33\%) after 6 weeks of primary culture of $W$. somnifera (Table 1 ). The colour of friable callus is greenish whitish. Callus induction was reported by many workers from various explants of $W$. somnifera. Sharma et al. (2010) reported maximum callusing (100\%) from root and cotyledonary leaf segments grown on MS medium supplemented with a combination of $2 \mathrm{mgL}-1$ 2,4-D 
and $0.2 \mathrm{mgL}-1$ Kinetin which are in agreement with present study. Arumugam and Gopinath (2011) also observed best callus initiation in MS media supplemented with 1.0-5.0 $\mathrm{mg} / \mathrm{L} 2,4-\mathrm{D}$ after 16-20 days $(93 \%)$ in $W$. somnifera. The response of callus growth increases gradually with the reductions in concentration of KIN in culture medium of both the explants. The concentration of 2, 4-D was kept constant. The callus growth was inversely proposal to callus induction.

\section{Conclusion}

An efficient protocol for induction and proliferation of callus of $W$. somnifera using shoot apex and leaf explants has been developed. This protocol might be useful for the production and isolation of metabolites in callus culture as the natural propagation of $W$. somnifera is time taking because of long germination period and low levels of seed germination. Furthermore, this standardized callus induction and proliferation protocol might be used in further research for mass propagation of $W$. somnifera via indirect regeneration methods.

\section{REFERENCES}

Adhikari, S R and Pant, Bijaya (2013).Induction and proliferation of in vitro mass of callus of Withania somnifera (L.) Dunal. Research in Plant Sciences. 1 (3):58-61.

Arumugam, A. And Gopinath,K.(2011). Micro propagation and tissue culture of the endangered medicinal plant Withania somnifera by the direct shoot and root initiation method. International Journal of Applied Biology and Phermaceutical Technology. 2(3):315-321.

Gibson, D. M., Ketchum, R. E. B., Hirasuna, T. J., Shuler, M. L.( 1995). Potential of plant cell culture for Taxol production." Science and Applications.

Hina, T., Ali, S., Asi, M.R.(2012).Appraisal of an important Flavonoid, Quercetin, in callus cultures of Citrullus colocynthis." International Journal of Agriculture and Biology, 14(4). 528-532.

Kavidra, N.T., Neelesh, C.S., Vaibhav, T. and Brahma, D. (2000). Micropropagation of Centella asiatica (L.) a valuable medicinal herb. Plant Cell Tiss. Org. Cult., 62:175-179.

Kulkarni, A.A; Thengane, SR and Krishnamurthy, KV. (2000). Direct shoot regeneration from node, internode, hypocotyls and embryo explants of Withania somnifera. Plant Cell, Tissue and Organ Culture. 62: 203-209.

NRIF (2004). Pliot study on "Mechanism for sustainable development and promotion of Herbal and Medicinal plants (H\&MP) in the state of Uttaranchal (India). Report forwarded to SER Division, Planning commission, India by Natural Resources India Foundation, New Delhi, 205.

Patel, P. and Krishnamurthy, R.(2013). Feasibility studies on in vitro mass-scale propagation of Indian Ashwagandha (Withania somnifera) cultivars for commercial purpose.
Journal of Pharmacognosy and Phytochemistry, 2 (2):168-174.

Pierik, R. L. M. (1987) "In-vitro culture of higher plants" Martinus Nijhoff Publishers, Dordrecht, The Netherlands

Rani, A., Kumar, M. and Kumar S.(2014). In vitro propagation of Withania somnifera (L.) Dunal. from shoot apex explants. Journal of Applied and Natural Science 6 (1): 159-163

Rani, A., Kumar,M. and Kumar S.(2015) a . Conservation of endangered medicinal plants through plant tissue culture. Conservation And cultivation of medicinal plants Tilak was an.Discovery publishing house pvt. Ltd. ISBN No: 978-93-5056-740-1: 67-95.

Rani, A., Kumar,M. and Kumar S.(2015) ${ }^{\mathrm{b}}$. Ashwagandha-a miracle medicinal crop. Medicinal plant (distribution, utilization and significance). Tilak was an.Discovery publishing house pvt. Ltd. ISBN no: 978-93-5056-7340: 174-197.

Rani, G.and Grover, I.S.(1999).In vitro callus induction and regeneration studies in Withania somnifera. Plant Cell Tiss Org Cult .57: 23-27.

Rani G, Virk G. S. and Nagpal A (2003) Callus induction and plantlet regeneration in Withania somnifera (L.) Dunal. In Vitro Cell. Dev. Biol. Plant 39: 468-474

Rout, Ranjan Jyoti ., Sahoo, Santi lata and Das, Ritarani. (2011). An attempt to conserve Withania somnifera (1.) Dunal - a highly essential medicinal plant, through in vitro callus culture. Pak. J. Bot, 43(4): 1837-1842.

Rajeswara Rao BR., Rajput DK., Nagaraju G. and Adinarayana G.(2012).Opportunities and challenges in the cultivation of Ashwagandha \{Withania somnifera (1.) Dunal\} Journal of pharmacognosy .3(2):88-91.

Schielder, O. (1985). Possibilities of plant cell culture for the improvement of medicinal plants. Pharm. Ztg. 130 (37): 2309-2310.

Sharma, P. K., Singh, G., Dudhe, R. and Singh, S. (2010).Biological activities of Withania somnifera. Anul of Bio Research 1 (3). 56-63.

Shanmugaratnam Suvanthini, Mikunthan Gunasingham and Thurairatnam Shyama. (2013).Potential of Withania somnifera Dunal Cultivation as a Medicinal Crop in Jaffna District. American-Eurasian J. Agric. \& Environ. Sci.13 (3): 357-361.

Supe, U., Dhote, F. and Roymon, M.G. (2006). In vitro Plant Regeneration of Withania somnifera. Plant Tiss. Cult. Biotech, 16:111-115.

Udayakumar R; Choi C W; Kim K T; Kim SC; Kasthurirengan S;Mariashibu TS; Sahaya Rayan JJ and Ganapathi A.(2013). In vitro plant regeneration from epicotyl explant of Withania somnifera (L.) Dunal.Journal of Medicinal Plants Research. 7(1): 43-52.

Vadawale, AV; Bhatt PA and Dave, AM. 2004.Rapid propagation of Ashwagandha (Withania somnifera) through axillary bud multiplication and indirect organogenesis. Phytomorphology. 54(1\&2) : 59-64.

Waman, A.A., U. Konana, S.B. Narayanappa, A. Tholakalabavi and B. Gowda, 2011. Callus Culture and Plant Regeneration from Seedling Explants in 'Poshita' Indian Ginseng. Horticulture \&Environment Biotechnology. 52 (1): 83-88. 